\title{
Histological and Biochemical Study on the Estrogen Role in Indomethacin-induced Gastric Ulcer of Menopausal Rats
}

\section{Original Article}

\author{
Dalia A. Mohamed', Samah M. Ahmed ${ }^{1}$, Sally M. Shalaby' ${ }^{2}$ and Eman Abd Elkader ${ }^{2}$ \\ Departments of Histology and Cell Biology ${ }^{1}$, Departments of Medical Biochemistry ${ }^{2}$, Faculty \\ of Medicine, Zagazig University, Zagazig, Egypt
}

\begin{abstract}
Background: Estrogen is a principal female sex hormone that originally characterized by its importance in sexual growth and reproduction. Nevertheless, emergent evidence proposes clinical relationship between estrogen/ estrogen receptors and gastric diseases. This association is definitely under several investigated topics.

Aim: The current study designed to explore exogenous estrogen effect on indomethacin-induced gastric ulcers in postmenopausal female rats.

Matrial and methods: Twenty-four female rats $(200 \pm 20$ gram BW) were allocated randomly into four groups; control, ulcer-induced, ranitidine-treated and (ranitidine\&estradiol velerate) combined-treated group. Animal in all group except control subjected to ovariectomy to assimilate menopausal condition. At end of the experiment, the stomach fundus examined macroscopically to assess the ulcer severity and ulcer score in different groups. Histopatholgical and biochemical evaluation also were performed and all results were statistically analyzed.

Results: Indomethacin-induced gastric ulcer in ovariectomized rats showed destroyed fundic mucosa and mucus layer, increase oxidative stress markers, inflammatory mediators and myeloperoxidase. Treatment with ranitidine attenuated the histological and biochemical changes but within limits. Better improvement was accomplished when ranitidine combined with estrogen.

Conclusion: The postmenopausal women should be supplemented with estrogen not only to control menopausal symptoms but also to protect and maintain gastric mucosal integrity.
\end{abstract}

Received: 05 Feb 2019, Accepted: 26 Feb 2019

Key Words: Estrogen, gastric ulcer, menopause, rats

Corresponding Author: Dalia A Mohamed, Assistant professor of Histology and Cell Biology, Faculty of Medicine, Zagazig University, Zagazig, Egypt, Tel.: +201223168887, E-mail: daliafarag@gmail.com.

ISSN: 2536-9172, Dec 2018 Vol.2, No.2

\section{INTRODUCTION}

Nowadays, gastric ulcer is measured as new plague of the $21^{\text {st }}$ century $^{[1]}$. It is the common gastrointestinal (GIT) and global disorder that occurs mainly due to many destructive factors of the mucosal barrier and/or imbalance between the destructive and defensive ones ${ }^{[2]}$. The multifactorial destructors include stress, increased hydrochloric acid $(\mathrm{HCl})$, mucosal hypoperfusion, Helicobacter pylori and undue ingestion of nonsteroidal anti-inflammatory (NSAI) drugs. Indeed, mucosa of stomach is incessantly exposed various irritants that impair its integrity and lead to development of acute and chronic ulcers ${ }^{[3]}$.

It is widely accepted that gastric ulcerations are linked to hormonal cycles fluctuations, particularly sex hormones ${ }^{[4]}$. Different studies in animal and humans documented that gastric acid secretion influenced by sex hormones that maintain the gastroduodenal mucosa integrity . Confirmatory studies emphasized that gastric ulcer formation reduced in female rats as compared to male with significantly faster ulcer healing ${ }^{[5,6]}$. Several epidemiological studies have shown that women during pregnancy or taking estrogen containing pills displayed reduced frequency of gastric ulceration ${ }^{[7]}$.Statistically, peptic ulcer occurred in higher incidence among menopausal women ${ }^{[8]}$.

Although peptic ulcer disease recognized as a distinct pathology, the proposed mechanisms of its etiopathogenesis change every year with advanced research. Recently, various findings reported deep contribution of female sex hormones (estrogen) in the pathophysiological mechanisms of peptic ulceration ${ }^{[9]}$. Estrogen is a steroid hormones synthesized principally in reproductive tissues as both ovary and placenta. Also, It created in non-reproductive extraovarian tissues inminor amount; as breast, liver, adrenal gland, fatty tissue and GIT ${ }^{[10,11]}$. It is generally supposed that estrogen has imperative role in bone, cardiovascular, gastrointestinal and in the central nervous system. several clinical studies and huge observational data recommended exogenous estrogen administration for the health of menopausal women ${ }^{[12]}$.

Estrogen has various physiological functions such as growth and differentiation, via its endocrine, autocrine 
or paracrine ways. Although GIT considered as nonsteroid targeted organ, functional estrogen receptor (ER) identification in it indicating its physiological roles and estrogen in those system ${ }^{[13]}$. It was reported that regulation of duodenal mucosal HCO3- secretion by estrogen could contribute in duodenum mucosa protection from acid induced damage and minimizing duodenal ulcer formation risk. Also, estrogen could decrease $\mathrm{Cl}$ - secretion in colon ${ }^{[14]}$.

The Protective effect of hormone replacement therapy(HRT) through estrogen and its receptors in GIT diseases is considered as confirmatory clinical implication . In postmenopausal period, HRT considered as protective way from many illness activities in females that render them having less likely experience of some diseases flaring. Such study reported that decreased risk of gastroesophageal adenocarcinoma and esophageal squamous cell carcinoma menopausal hormone therapy users ${ }^{[15]}$

The of Gastric ulcer prevention/treatment is curcial medical challenge. In spite of large number of available drugs for treatment of gastric ulcers, their major disadvantages, as limited drug efficacy and serious side effects, necessitate a continual search for new antiulcer therapies. Moreover, gastric ulcer considered as a multietiological disease so drugs with multiple modes of actions may be helpful in attenuation of gastric ulcers ${ }^{[9,16]}$.

Female steroids mainly estrogen are broadly used in hormone replacement therapy and as contraceptives way. Considering all reported interesting yet confusing findings regarding antiulcer effect of estrogen ${ }^{[17]}$, little literature investigated its possibility in gastric ulcer prevention of postmenopausal women. So, the current study planned to explore the possible protective effect of these ovarian sex hormone(estrogen) on indomethacin-induced gastric ulcers in ovariectomized female rats.

\section{MATERIALS AND METHODS}

\section{Materials}

\section{- Animals:}

Female albino rats weighting $(200 \pm 20 \mathrm{~g}$ b.wt.) obtained from Animal House Faculty of medicine, Zagazig University for this experiment. All animals were retained in stainless steel cages with controlled temperature $(23 \pm 1 \mathrm{EC})$ and artificially illuminated environment (12 $\mathrm{h}$ dark/light cycle).The room should be free from any source of contamination and the animals were provided with standard laboratory diet/water ad libitum. Animal procedures were performed in accordance with the Ethics Committee of the National Research Centre and followed the recommendations of Faculty of Medicine, Zagazig University for Care and Use of Laboratory Animals.

\section{- Drugs and chemicals:}

Indomethacin ( $\geq 99 \%, 100 \mathrm{~g}$ powder) and Ranitidine hydrochloride were purchased from Sigma Chemical Co., St. Louis, MO, USA and both were dissolved in distilled water. Estradiol valerate purchased from JHP pharmaceutical Inc. as $5 \mathrm{ml} / 1$ multidose vial dissolved in sessim oil (10mg/1ml). All other used chemicals had good quality and analytical grade.

\section{Methods}

- Ovariectomy procedure:.

For ovariectomy (OVX), rat females were anaesthetized with pentobarbital sodium anesthesia (50 mg/kg ip). An incision $10 \mathrm{~mm}$ was made in lower abdomen. The skin over area separated from underlying muscles, then muscle fibers incised and placed a forceps at boundary between the oviduct and the uterus. After ligation of ovarian arteries, both ovaries were removed. Then the uterus was put back into the abdominal cavity and the incision was closed with 4-0 nylon sutures. Each OVX animal received prophylactic dose of $0.1 \mathrm{ml}$ Penicillin G procaine $(300,000$ unit ml1, Phoenix Pharmaceutical Inc., St. Joseph, MO) by intramuscular injection. In sham operated animals, similar surgical procedure occured with exposing the ovaries then putting them in the same position only ${ }^{[18]}$.

\section{- Ulcer Induction:}

After acclimatization 7 Days period later, All ovariectomized (OVX) rats were fasted $24 \mathrm{~h}$ before indomethacin oral treatment; during this period, the rats were kept in wide wire mesh-bottom cages to avoid coprophagia. Additionally, water access prevented for $2 \mathrm{~h}$ before the indomethacin dosing. Four hours after the single oral dose $(40 \mathrm{mg} / \mathrm{kg} / \mathrm{BW})$ of indomethacin, all rats were started treatment either with ranitidine alone or combined ranitidine and estradiol ${ }^{[19]}$

\section{Experimental design:}

Twenty-four animals were used in this study and were divided randomly and equally into four groups.

Group I \{control\}: were further subdivided into 3 subgroups;

Ia $\{$ negative control $\}$ : non operated nor treated rats

Ib \{postive control\}: received sesam oil as vehicle for estradiol.

Ic $\{$ sham-operated $\}$ : underwent a similar surgical ovariecctomy procedure, but without ovaries removal. 
Group II \{ulcer-induced\}: overectomized females were received indomethacin $40 \mathrm{mg} / \mathrm{kg}$ orally once for ulcer induction, 7 days after the operation ${ }^{[20]}$

Group III \{ranitidine-treated\}: OVX females treated with ranitidine $50 \mathrm{mg} / \mathrm{kg}$ once orally (used as a standard reference drug) starting 7 days post operation for 4 successive weeks ${ }^{[1]}$.

Group IV \{combined-treated group\}: rats were treated with both ranitidine and estradiol velerate $(1.0 \mathrm{mg} / \mathrm{kg})$ injected IM at a volume of $0.2 \mathrm{ml} / 100 \mathrm{~g}$ body weight, once per week for 4 weeks starting 7 days post operation ${ }^{[21]}$.

At the end of the experiment, all animals were anaesthetised by IP injection of $(25 \mathrm{mg} / \mathrm{kg})$ sodium thiopental and the stomachs (fundus) were excised for macroscopic, microscopic and biochemical examination.

\section{Evaluation of fundic mucosal injury}

The stomach fundi collected, opened along their greater curvatures, followed by gentle saline washing to remove the contents and pinned out on a wax platform. The fundic areas stomach surfaces macroscopically evaluated to determine the ulcer area (indicating severity) and the ulcer score. The ulcer area was measured on the paper rulers with the scale of $\mathrm{mm} 2$. However, the lesions were scored counting on their severity between 1 and 6 , as in Table (1). Then, gastric ulcer index calculated as follow:

Ulcer index $=$ mean ulcer score of similarly treated group $\mathrm{x}$ percentage of unlcerated animals of the same group $^{[22,23]}$

Table 1: scoring of the ulcer

\begin{tabular}{lc}
\hline Ulcer area mm (severity) & Score \\
\hline No damage & 0 \\
Mild redness & 1 \\
Superficial lesion & 2 \\
Deep lesions & 3 \\
Penentreted ulcer & 4 \\
\hline
\end{tabular}

II. Biochemical assays:

Estimation of oxidative stress biomarkers in serum and gastric tissue

Blood samples were collected in centrifuge tubes then allow clotting for serum separation. Centrifugation at 3000 rpm for 15 minutes induced clear non-hemolysed sera that used for antioxidants activity assay: catalase (CAT) ${ }^{[24]}$, superoxide dismutase (SOD) ${ }^{[25]}$ as well as determination of malondialdehyde (MDA) level concentrations ${ }^{[26]}$.

After scarification, the fundic mucosa was quickly scraped using two glass slides from and immediately homogenized in ice cold $0.1 \mathrm{M}$ Tris- $\mathrm{HCl}$ buffer ( $\mathrm{pH}$ 7.4). The aliquot was kept frozen until the determination of oxidative stress biomarkers (reduced glutathione; GSH and MDA) in gastric mucosal tissues.

Concentrations of tumour necrosis factor- $\alpha(\mathrm{TNF}-\alpha)$ and myeloperoxidase enzyme (MPO) were estimated in fundic mucosal tissue also. Part of gastric tissue homogenates were used for analysis of ER $\alpha$ and ER $\beta$ gene expression.

\section{Determination of gastric mucosal tissue $T N F-\alpha$ levels}

Fundic tissue TNF- $\alpha$ concentration was determined in gastric homogenate using enzyme-linked immunosorbent assay kit (rat TNF- $\alpha$ ELISA kit, Biosource, Belgium) according to the manufacturer's protocol. TNF- $\alpha$ concentrations expressed as $\mathrm{pg} / \mathrm{g}$ tissue.

\section{Determination of gastric mucosal tissue myeloperoxidase (MPO) concentration}

MPO concentration was measured in gastric fundic mucosal tissue homogenate consuming rat enzyme-linked immunosorbent assay kit (rat MPO ELISA kit, Wkea Med Supplies Corp, China) according to manufacturer protocol. MPO concentrations expressed as ng/g tissue

III. Real time PCR for estrogen receptors $\alpha$ and $\beta$ (ER $\alpha$ and $\operatorname{ER} \beta$ ) gene expression

- Total RNA extraction and cDNA Synthesis

Total RNA was isolated from fundic tissue homogenate using the RNeasy Mini kit following the manufacturer's protocol (QIAGEN, Germany). The RNA was then reverse transcribed by the use of Quantiscript reverse transcriptase (QuantiTect Reverse Transcription Kit, QIAGEN, Germany).

\section{- Real-Time PCR Analysis}

The cDNA were used for determination of the ER $\alpha$ and ER $\beta$ gene expression. Rat ribosomal protein (RPL19) was used as a housekeeping gene.Quantitative real-time PCR analysis was performed with a Mx3005 P (Stratagene, La Jolla, CA, USA) in a mixture containing $5 \mu \mathrm{L}$ of the cDNA, $100 \mathrm{pmol} / \mu \mathrm{L}$ of each primer $(0.5 \mu \mathrm{l}$ each; Biolegio, Gelderland, The Netherlands), $10 \mu \mathrm{L}$ of EvaGreen PCR Master mix (Jena Bioscience, Jena, Germany), and $4 \mu \mathrm{L}$ PCR-grade water.

The sequence of the primers used is ER $\alpha$, sense; 5' AAT TCT GAC AAT CGA CGC CAG-3', ER $\alpha$ antisense; 5'-GTG CTT CAA CAT TCT CCC TCC TC-3', ER $\beta$ sense; 5'-TTC CCG GCA GCA CCA GTA ACC-3', ER $\beta$ antisense; 5'-TCC CTC TTT GCG TTT GGA CTA-3', RPL19 sense; 5'-GAA ATC GCC AAT GCC AAC TC-3', 
RPL19 antisense; 5'-ACC TTC AGG TAC AGG CTG TG$3^{\prime[27]}$. The following thermal cycling conditions were used; initial denaturation and enzyme activation at $95^{\circ} \mathrm{C}$ for 5 min, followed by 40 cycles of denaturation at $95^{\circ} \mathrm{C}$ for 15 sec, annealing at $\left(30^{\circ} \mathrm{C}\right.$ for $\mathrm{ER} \alpha, 33^{\circ} \mathrm{C}$ for $\mathrm{ER} \beta$ and $24^{\circ} \mathrm{C}$ for RPL19) for $15 \mathrm{sec}$, and extension at $72{ }^{\circ} \mathrm{C}$ for $1 \mathrm{~min}$. Relative changes in gene expression were calculated using the $2^{-\Delta \Delta \mathrm{CT}}$ method described by ${ }^{[28]}$.

\section{Histological examination (29):}

\section{- Hematoxylin and Eosin:}

Part of fundic tissue from all different groups were fixed in $10 \%$ buffered formalin and then sectioned by microtome (Leica, Germany). Sections of $5 \mathrm{~mm}$ thickness cut and stained with hematoxylin and eosin.

- Mallory trichrome:

For identification of collagen fibers

- PAS-Alcian staining:

Other Sections of the glandular layer of gastric tissue were stained with periodic acid Schiff(PAS) to differentiate the acidic and basic glycoproteins level in the mucus.

\section{- Immunohistochemical evaluation:}

The slides were deparaffinized and rehydrated followed by washing by Tris Buffered Saline automation buffer (Biocare Medical, CA). Endogenous peroxidase was appeased by incubating tissue sections with $3 \%$ hydrogen peroxide. Endogenous biotin with nonspecific binding of avidin/biotin were blocked using an avidin-biotin blocking kit (Vector Laboratories, CA) after that, all sections were incubated with primary antibody. Subsequently, the sections were incubated with the secondary antibody followed by Vectastain Elite ABC kit (Vector Laboratories, CA) for $30 \mathrm{~min}$. Antigen/antibody complex could be visualized using 3,3'-diaminobenzidine (DAB) chromogen. Lastly, the slides were counterstained with hematoxylin and cover slipped. Negative controls prepared by incubation the tissue sections either with normal serum in which the primary antibody was raised or by normal mouse IgG.

\section{Scanning electron microscopy (SEM):}

Other part of the same specimens were fixed in an aldehyde mixture of $4 \%$ formaldhyde, $1.25 \%$ glutaraldhyde and $10 \mathrm{nmol} / 1$ cacodylate buffer. Then all samples were dehydrated in ethanol and critical point-dried in a Balzer's apparatus using carbon dioxide as the transitional fluid. The preparations were mounted on metal stubs with conductive carbon paste. The specimens coated with $\mathrm{Au} / \mathrm{Pt}$ under vacuum and examined in a [JEOL (Japan) JSM $6510 \mathrm{lv}$ ] scanning electron microscope, Faculty of Agriculture, Al Mansoura University, Egypt. The instrumental conditions for the observations were $15 \mathrm{~kW}, 0.2 \mathrm{nA}, 30 \mathrm{~s} /$ frame (photography) ${ }^{[30]}$.

VI. Statistical analysis:

The data were expressed as mean $\pm \mathrm{SD}$ for each group. Results were analyzed using one way analysis of variance (ANOVA) for comparison between the different groups. Then, followed by LSD test for multiple comparisons using SPSS version 17 statitical program. The $p<0.05$ was considered as being significant in all types of statistical tests.

\section{RESULTS}

I. Macroscopic results

No visible sign of ulceration was detected in control animals group. Indomethacin induced obvious lesions in treated animals. The average ulcer severity and score were greater than other groups (Table2, Fig.1,2). However, treatment with ranitidine significantly decrease the gastric severity and score with significant difference from group II. In group IV with combined treatment, there was higher statistically significant difference in ulcer severity and score from group II and significant difference from group III.Group IV showed high prevention than group III (Table 2, Fig.1,2).

Table 2: Effect of oral administration of ranitidine, estradiol on ulcer induction by indomethacin in rats on mean ulcer score, ulcer index and preventive index

\begin{tabular}{lcccc}
\hline Group & $\begin{array}{c}\text { Ulcer area in } \\
\mathrm{mm} 2\end{array}$ & $\begin{array}{c}\text { Mean ulcer } \\
\text { score }\end{array}$ & Ulcer index & $\begin{array}{c}\text { Preventive } \\
\text { index (\%) }\end{array}$ \\
\hline Group II & $28.40 \pm 1.39$ & $4.70 \pm 0.15^{\#}$ & $10.6 \pm 2.013^{\#}$ & Zero \\
Group III & $20.71 \pm 0.88^{*}$ & $2.2 \pm 2.23^{*}$ & $5.2 \pm 0.31$ & 75.9 \\
Group IV & $12.3 \pm 1.8^{*} \#$ & $1.6 \pm 0.32 \#^{*}$ & $2.7 \pm 0.14$ & 90.1 \\
\hline
\end{tabular}

$* \mathrm{P}<0.001$ compared to indomethacin induced ulcer $\# \mathrm{P}<0.05$ compared to ranitidine treated

Fig. 1: ulcer area $\mathrm{mm}$ in all groups

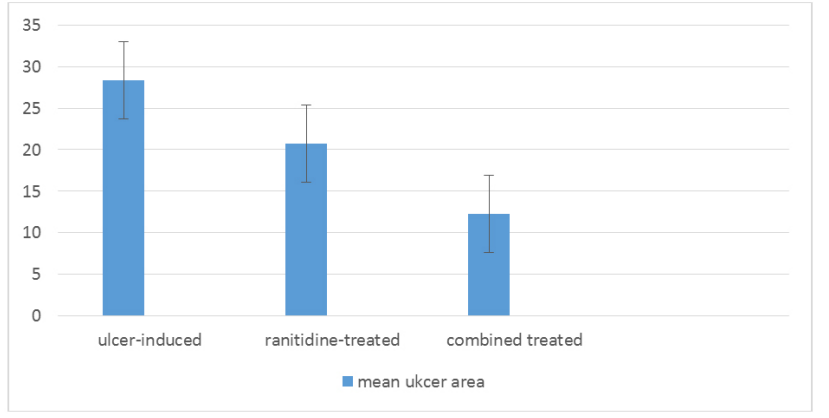


Fig.2: ulcer score and index in all groups

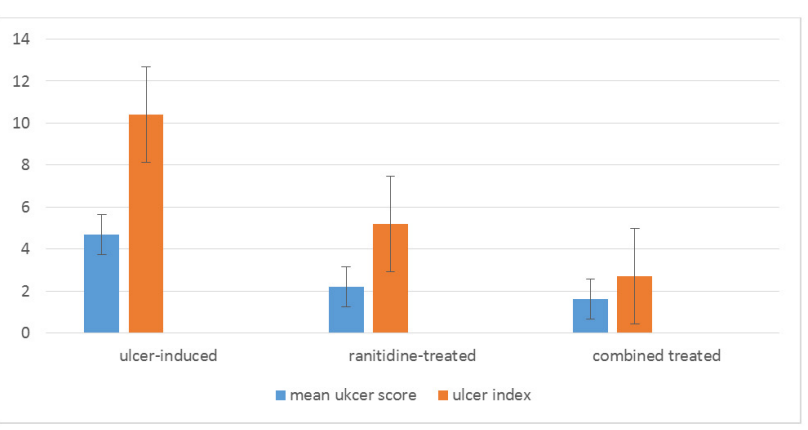

II. Biochemical results

- Quantitative estimation of gastric mucosal contents of TNF- $\alpha$ and MPO:

Gastric (fundic) TNF- $\alpha$ was significantly increased in indomethacin group when compared with normal control $(p<0.001)$. Treatment with ranitidine or ranitidine + estradiol decreased gastric TNF- $\alpha$ level significantly when compared with indomethacin induced ulcer group $(\mathrm{p}<0.001$ for each). Rats treated with indomethacin showed an increase in MPO contents to give a high value as compared to the control group indicating enhancement of neutrophils infiltration into mucosal tissues. Administration of ranitidine or combined ranitidine with estradiol reduced the elevated MPO level by significant level $(\mathrm{p}<0.001)$. Ranitidine + estradiol treated group showed a significant decrease of TNF- $\alpha$ and MPO levels when compared to rats treated by ranitidine $(\mathrm{p}<0.001$ for each) meaning that ranitidine + estradiol treatment showed better effects than treatment by ranitidine only (Table 3 ).
Table 3: Effect of oral administration of ranitidin, estradiole on ulcer induction by indomethacin in rats on MPO and TNF- $\alpha$ levels

\begin{tabular}{lll}
\hline Group & MPO (ng/g tissue) & $\begin{array}{l}\text { TNF- } \alpha \quad(\mathrm{pg} / \mathrm{g} \\
\text { tissue) }\end{array}$ \\
\hline Control & $12.4 \pm 3.2$ & $19.2 \pm 3.5$ \\
Indomethacin induced ulcer & $44.6 \pm 5.3^{*}$ & $60.5 \pm 5.6^{*}$ \\
Ranitidine treated & $23.8 \pm 2.6^{* \#}$ & $39.4 \pm 4.7^{* \#}$ \\
Ranitidine+estradiol & $15.6 \pm 4.5 \# \$$ & $23.1 \pm 2.3^{*} \# \$$ \\
\hline
\end{tabular}

$* \mathrm{P}<0.05$ when compared to control

${ }^{\$} \mathrm{P}<0.05$ when compared to indomethacin induced ulcer

${ }^{*} \mathrm{P}<0.05$ when compared to ranitidine treated

$\mathrm{N}=8$ rats/group

- Determination of gastric mucosal oxidative stress and enzymatic antioxidant activity:

Antioxidant potential of estradiole was determined by estimation of serum catalase activity, SOD activity and MDA levels and determination of GSH and MDA in gastric fundic tissues. There was a significant decrease of antioxidant enzymes activity and an increase of MDA levels in both serum and tissue of indomethacin induced ulcer rats when compared to controls.

Treatment with estradiole showed significant increase of the antioxidant enzymes activities, increase of GSH values and significant decrease of MDA levels as compared to gastric ulcer rats. Moreover, treated group with ranitidine + estradiole showed better results than treated group with ranitidine only (Table 4).

Table 4: Serum and tissue oxidant and antioxidant markers in studied groups

\begin{tabular}{llllll}
\hline Groups & $\begin{array}{l}\text { Catalase activity } \\
(\mathrm{U} / \mathrm{mL})\end{array}$ & $\begin{array}{l}\text { Superoxide } \\
\text { dismutase }(\mathrm{SOD})(\mathrm{U} / \mathrm{ml})\end{array}$ & $\begin{array}{l}\text { Malondialdhyde } \\
(\mathrm{MDA}) \\
(\mathrm{nmol} / \mathrm{ml})\end{array}$ & $\begin{array}{l}\text { Tissue reduced } \\
\text { glutathione } \\
\mathrm{nmol} / \mathrm{mg}\end{array}$ & $\begin{array}{l}\text { Tissue MDA } \\
\mathrm{nmol} / \mathrm{mg}\end{array}$ \\
\hline Control & $234.65 \pm 35.14$ & $88.25 \pm 8.34$ & $4.56 \pm 1.23$ & $6.32 \pm 1.42$ & $2.35 \pm 1.65$ \\
Indomethacin induced ulcer & $115.10 \pm 21.20^{*}$ & $60.10 \pm 6.56^{*}$ & $54.60 \pm 1.58^{*}$ & $1.52 \pm 0.54 *$ & $10.15 \pm 2.30^{*}$ \\
Ranitidine treated & $188.26 \pm 15.51 * \$$ & $66.76 \pm 11.34^{*}$ & $20.33 \pm 1.54 * \$$ & $3.15 \pm 0.18^{*} \$$ & $8.23 \pm 2.45 * \$$ \\
Ranitidine+estradiole & $200.64 \pm 24.27 * \$$ & $84.22 \pm 9.67 \$$ & $11.08 \pm 1.67 * \$ \#$ & $5.12 \pm 2.37 \$ \#$ & $5.34 \pm 2.12 * \$ \#$ \\
\hline
\end{tabular}

$* \mathrm{P}<0.05$ when compared to control

${ }^{\mathrm{S}} \mathrm{P}<0.05$ when compared to indomethacin induced ulcer

${ }^{\#} \mathrm{P}<0.05$ when compared to ranitidine treated

$\mathrm{N}=10$ rats/ group

- Effects of estradiole on the mRNA expression levels of ER $\alpha$ and ER $\beta$ genes

A significant reduction of ER $\alpha$ and ER $\beta$ mRNA expression was found in the ulcer ovariectomized group when compared with controls. When comparing the group treated with ranitidine and estradiole to the untreated rats, we found a significant increase of expression of both ERo and ER $\beta$. Interestingly, the group treated with ranitidine and estradiole showed a significant up-regulation of the expression of both genes when compared to the treated rats with ranitidine only (Table 5). 
Table 5: Relative expression levels of ER $\alpha$ and ER $\beta$ in gastric homogenate in all studied groups

\begin{tabular}{lll}
\hline Groups & $\begin{array}{l}\text { Relative } \\
\text { expression } \\
\text { of ER } \alpha\end{array}$ & $\begin{array}{l}\text { Relative } \\
\text { expression } \\
\text { of ER } \beta\end{array}$ \\
\hline control & $1.0 \pm 0.01$ & $1.0 \pm 0.04$ \\
Indomethacin induced ulcer & $0.62 \pm 0.12 *$ & $0.75 \pm 0.15 *$ \\
Ranitidine treated & $1.2 \pm 0.31 \$$ & $1.3 \pm 0.17 * \$$ \\
Ranitidine-estradiole & $2.34 \pm 0.83 * \$ \#$ & $3.2 \pm 0.53 * \$ \#$ \\
\hline
\end{tabular}

$* \mathrm{P}<0.05$ when compared to control

$\$ \mathrm{P}<0.05$ when compared to indomethacin induced ulcer

${ }^{\#} \mathrm{P}<0.05$ when compared to ranitidine treated

$\mathrm{N}=10$ rats/group

\section{Histological results:}

Histological examination of all control subgroups showed no noticeable histological differences between them. So, we considered the negative control subgroup 1a as main control group.

Hematoxylin and eosin (H\&E) stained sections of control fundic mucosa revealed three mucosal layers; epithelial lining, lamina propria (LP) and muscularis mucosa. Fundic glands occupied the whole thickness of LP and opened onto the surface through narrow gastric pits (Fig. 3a). Surface mucous cells contained basal nuclei and foamy cytoplasm and mucous neck cells appeared columnar with basal oval nuclei(Fig. 3b). Parietal cells showed eosinophilic cytoplasm with rounded nuclei. Chief cells were low columnar and had basal rounded nuclei and basophilic cytoplasm (Fig. 3c). Group II showed disquamated surface epithelial cells, wide gastric pits, Parietal cells had small dark sained nuclei. Chief cells had dark nuclei and were separated from their basal lamina(Figs. 3d \&e). Group III surface mucous cells had flattened nuclei and opened by narrow gastric pits onto the surface. Parietal cells appeare with rounded nuclei and eosinophilic cytoplasm, (Fig. 1f). Chief cells appeared with dark stained nuclei, marked separation between the cells and congested blood capillary were also observed (Fig. 3g). In group IV surface mucous cells contained basal nuclei and foamy cytoplasm while Parietal cells showed eosinophilic cytoplasm with rounded nuclei (Fig. $3 \mathrm{~h}$ ). Chief cells appeared as low columnar cells with basal rounded nuclei and basophilic cytoplasm (Fig. 3i)

Mallory trichrome stained sections of control group revealed minimal amount of collagen fibres in LP of fundic mucosa (Fig. 4a). Increased collagen fibers in the LP of fundic mucosa in Group II (Fig. 4b). Moderate amount of collagen fibers detected in LP of fundic mucosa of group III (Fig. 4c). In group IV, very thin collagen fibers were seen in LP between the basal fundic glands (Fig. 4d).

PAS-alcian blue stained sections of control group showed strong positive PAS reaction in the thick mucus film overlying surface epithelium and extended down through gastric pits. Also, neck region contained Alcian. Acidic mucus in the neck and basal part was stained blue (Fig. 5a). groupII revealed faint positive PAS reaction through surface epithelium and mucous neck cells in the neck region of the glands. (Fig. 5b). In groupIII, Strong positive PAS reaction observed through mucous film covering the surface epithelium and extending to fill the gastric pits. Positive alcian blue stained the cells in neck region of the fundic glands was also seen (Fig. 5c). In groupIV, strong positive PAS reaction was detected in thin mucous film covering surface epithelium and extending to fill the gastric pits and strong positive alcian blue reaction in the mucous neck cells (Fig. 5d).

Immunohistochemical stained sections of the control group revealed strong chromogranin A immune reaction that appeared as dark brown color in the enteroendocrine cells cytoplasm (Fig.6a). Faint positive immuoreaction was seen in group II sections (Fig. 6b). Strong positive chromogranin A immuoreaction was detected in some enteroendocrine cells of groupIII (Fig. 6c). In group IV ,immunoperoxidase reaction for chromogranin-A revealed strong positive immuoreaction in chromogranin-A secreting cells cytoplasm (Fig.6d).

SEM of control group showed mucous sheet overlying whole surface of mucous cells with narrow gastric pits (Fig. 7a). Group II showed dilated gastric pits with loss of normal mucous sheet covering the surface cells and some globular mucous appeared (Fig. 7b). In group III some surface mucous cells covered by mucous sheet with globular mucous and narrow gastric pits (Fig. 7c). groupIV showed polymerized mucous sheet overlying most of surface mucous cells. Mucous cells were sprouted out from their narrow gastric pits with observable mucous patches (7d).

\section{DISCUSSION}

At menopausal period, the endogenic ovarian estrogen level went to decrease. Some peripheral tissues created locally the majority of those hormone through enzymatic conversion of steroid precursors. Concerning the possible effects of sex steroids on gastrointestinal(GIT) function, it was mentiones that GIT ulceration developed in sexually dependent manner and linked to sex hormonal changes ${ }^{[17,31]}$

In this study, indomethacin administration induced remarkably high ulcer index when compared to control group. Treatment with Ranitidine offered significant defense against indomethacin induced gastric ulcer in the experimental animals. It reduced ulcer index showing $75.9 \%$ prevention whereas combined treatment with ranitidine(RAN) and estrogen rather reduced ulcer index to showing $90.1 \%$ prevention. Therefore, combined treatment of rats with both drugs produced higher gastroprotective effect as compared to RAN alone, against gastric mucosal 


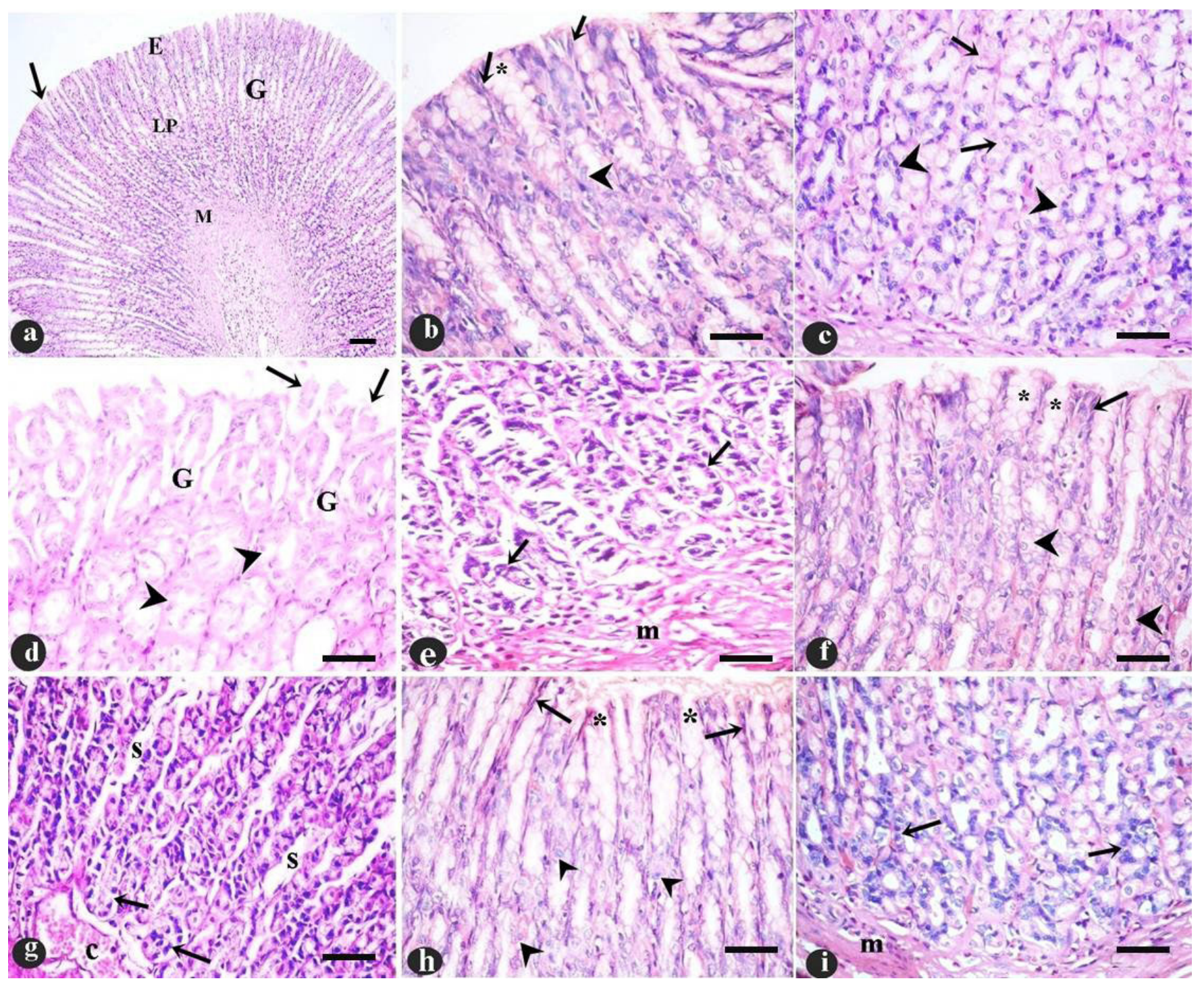

Fig. 3: (a): H\&E stained sections of the control fundic mucosa reveal the mucosal layers; epithelial lining (E), lamina propria (LP) and muscularis mucosa $(\mathrm{M})$. Fundic glands $(\mathrm{G})$ occupying the whole thickness of the lamina propria and are opened into the surface through narrow gastric pits (arrow). (b): Surface mucous cells (arrow) had basal nuclei and foamy cytoplasm, mucous neck cells (arrow head) appear with basal oval nuclei, narrow gastric pits (*) are also detected. (c): Parietal cells (arrow) have eosinophilic cytoplasm and rounded nuclei. Chief cells (arrow head) have small rounded nuclei and basophilic cytoplasm. (d,e): Group II showing disorganized fundic glands (G), disquamated epithelial cells (arrow), Parietal cells have small dark sained nuclei (arrow head). Chief cells (arrow) have small pyknotic nuclei and the cells are detached from the basal lamina. Muscularis mucosa (m) is noticed. (f): Group III surface mucous cells (arrow) have flat nuclei,narrow gastric pits $(*)$. Parietal cells (arrow head) have rounded nuclei and eosinophilic cytoplasm. (g): Chief cells (arrow) have dark stained nuclei, marked separation (s) between the cells and congested blood capillary (c) are also observed. (h): In group IV surface mucous cells (arrow) have basal nuclei and foamy cytoplasm, narrow gastric pits (*). Parietal cells (arrow head) have eosinophilic cytoplasm and rounded nuclei (i):. Chief cells (arrow) have rounded nuclei and basophilic cytoplasm. Muscularis mucosa (m) is also noticed.(H\&E 1a $\times 100,50 \mu \mathrm{m} 1 \mathrm{~b}, \mathrm{c}, \mathrm{d}, \mathrm{e}, \mathrm{f}, \mathrm{g}, \mathrm{h}$ and $\mathrm{i} \times 400,30 \mu \mathrm{m})$ 


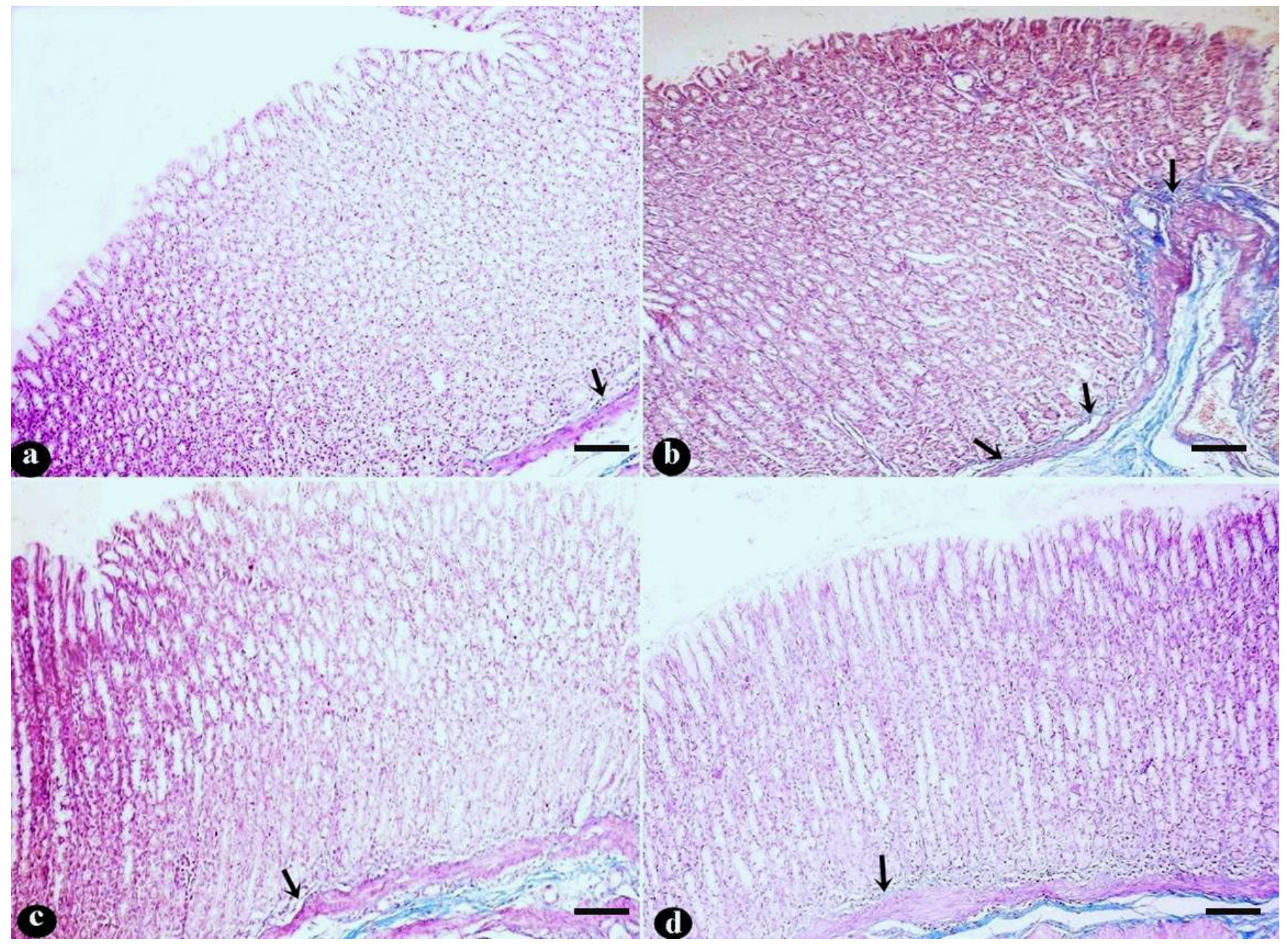

Fig 4: (a): Mallory trichrome stained sections of the control group showing minimal collagen fibres in the lamina propria of the fundic mucosa (arrow). (b): Large amount of collagen fibers (arrow) in the lamina propria of fundic mucosa are seen in Group II rats. (c): Moderate amount of collagen fibers (arrow) is detected in the lamina propria of the fundic mucosa of group III rats. (d): In group IV, very thin collagen fibers (arrow) is seen in the lamina propria between the basal fundic glands. (Mallory trichrome $\times 100,10 \mu \mathrm{m}$ )

injury. Several studies have suggested that gastric acid secretion influenced remarkably by sex hormones that contribute in the integrity of oral and gastroduodenal $\operatorname{mucosa}^{[32]}$.

In this work, it was documented increase the level of Tumor necrosis factor $(\mathrm{TNF}-\alpha)$ in indomethacin-induced ulcer group. However, excess release of $\mathrm{HCl}$ could be the core reason of that disease, Many clinicians and researches proved that increase (TNF- $\alpha$ ) is one of the key mechanism in mucosal injury in gastric ulcer. It is a proinflammatory cytokine released by macrophages increasingly during ulcerative stress. This factor stimulates apoptosis in epithelial and endothelial cells of gastric mucosa through caspase activation manner ${ }^{[33]}$. Although ranitidine showed a significant decrease in serum TNF- $\alpha$ which in accordance to $^{[34,35]}$. Estrogen is able to suppress leptin induced expression of TNF- $\alpha$ in cells of immune system. This finding could be of therapeutic value in women on hormone replacement therapy or women of reproductive age and risk of gastric ulcer. Many experimental and clinical-based studies emphasized that gender has an imperative role in gastro-doudenal mucosal ulcer occurennce ${ }^{[21]}$.

In the same context, our results revealed also increase MPO level in ulcer group with significant decrease in its level with groups III and IV respectively. There is evidence that TNF- $\alpha$ stimulates neutrophil infiltration into the gastric mucosa, and its overproduction increases the risk of gastric ulcer ${ }^{[35]}$. MPO (a neutrophil infiltration index) level is augmented following IND administration suggesting a role of TNF- $\alpha$ in neutrophil cells infiltration and in the development of gastric ulcer. MPO level activity is in direct proportion to neutrophil concentration in most inflamed tissue. In addition, increased MPO activity has been reported to be an index of neutrophil infiltration and inflammation ${ }^{[37]}$.whenever, ranitidine decrease MPO level, its administration with estrogen revealed better improvement.Several studies evaluated the effects of E2 on gastric cancer cell lines, gastric ulcerations, reporting hormonal positive effects after short term treatments with estradiol $^{[38]}$. 


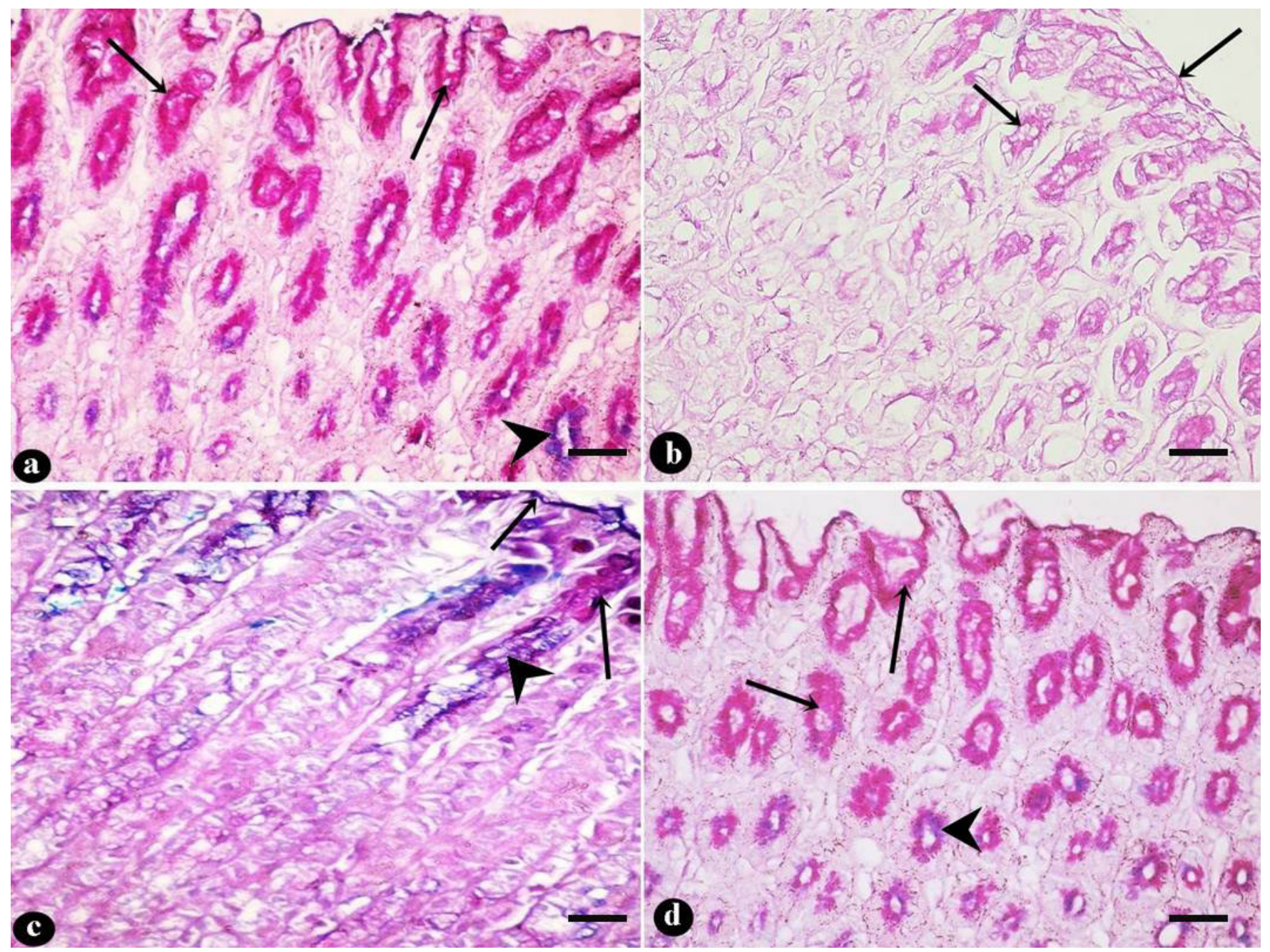

Fig 5: (a): PAS-alcian blue stained sections of the control group showing strong positive PAS reaction in the thick mucus film over the surface epithelium extending down into the gastric pits (arrow). Also, neck region contained acidic mucus in the neck and basal part is stained blue (arrow head). (b): GroupII reveals faint positive PAS reaction in the surface epithelium and the mucous neck cells in the neck region of the fundic glands (arrow). (c): In groupIII, strong positive PAS reaction is seen in the mucous film over the surface epithelium extending to fill the gastric pits (arrow). Positive alcian blue stained the mucous neck cells in the neck region of the fundic glands (arrow head) is also seen. (d): In groupIV, strong positive PAS reaction is detected in thin mucous film over the surface epithelium extending to fill the gastric pits (arrow) and strong positive alcian blue reaction in the mucous neck cells in the neck region of the fundic glands (arrow head). (PAS-alcian blue $\times 400,10 \mu \mathrm{m})$

In this study,histological examination of ulcerinduced ovariectomized rats (Group II) revealed shedding of surface epithelial cells, wide gastric pits and loss normal architecture. Parietal cells had dark stained nuclei and vacuolated cytoplasm. Also, chief cells appeared with dark nuclei and the cells were separated from their basal lamina. Gastric mucosa was congested and oxyntic cells were vacuolated. It was documented that gastric ulcers induced due to imbalances between the protective and destructive factors ${ }^{[39]}$. This group also revealed faint positive PAS reaction in the surface epithelium and mucous neck cells of the fundic glands.Indomethacin induced gastric ulceration and deep erosions by breaking the mucosal barrier ${ }^{[3]}$. This results confirmed by noticed absence in mucous cover in SEM examination and faint positive PAS staining. Some author reported that indomethacin induced prostaglandin $(\mathrm{PG})$ inhibition (prostaglandin E2,PGE2 \& prostaglandin 12,PG12) and disturbance of microcirculation ${ }^{[40]}$. PG inhibition also leads to gastric hypersecretion and dilatation of gastric glands that manifested by wide pits. Ovariectomy caused gastric barrier to convert more sensitive and decrease its components(mucus \& phospholipids) with decreasing in Calcitonin gene-related peptid level in gastric tissue ${ }^{[16]}$. Gastric ulcerations is interrelated to hormonal cycles changes, especially those linked to sex hormones secretion. So,It is accepted that peptic ulcers incidence increases among menopausal women ${ }^{[41]}$.

In this work, Ranitidine treated group (III) showed regularly arranged fundic glands with narrow gastric pits. Parietal cells had rounded nuclei and eosinophilic cytoplasm but some had dark stained nuclei and cytoplasmic remnants. Chief cells appeared with dark stained nuclei and there were marked separation between the cells. Ranitidine administration as traditional therapeutic schedule showed 


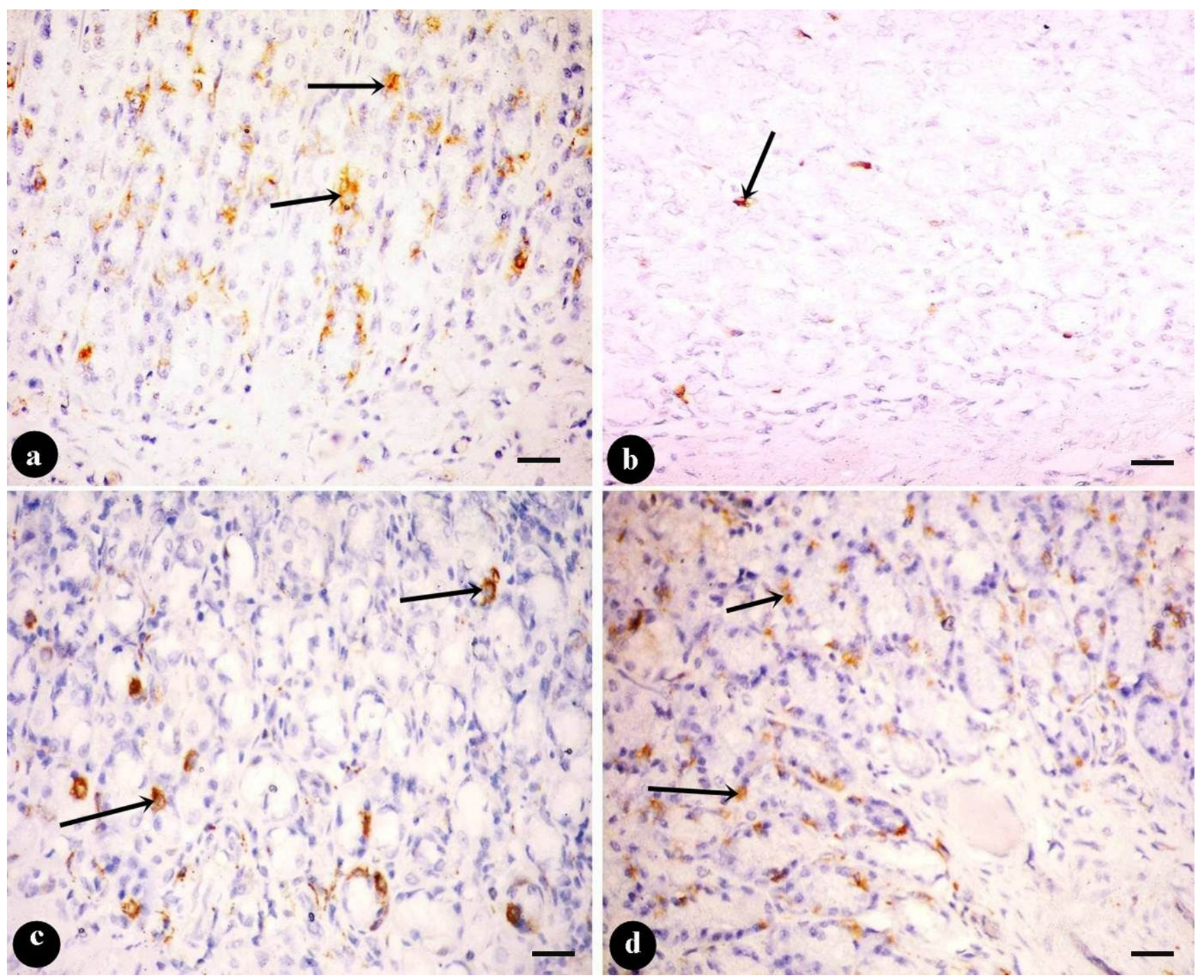

Fig 6: (a) Immunohistochemical stained sections of the control group showing strong chromogranin A immune reaction in many cells that appear as dark brown color in the enteroendocrine cells cytoplasm (arrow). (b): Faint positive immuoreaction in fewer cells is seen in group II sections (arrow). (c): Strong positive chromogranin A immuoreaction (arrow) is detected in some enteroendocrine cells of group III. (d): Immunoperoxidase reaction for chromogranin-A in group IV reveals strong positive immuoreaction (arrow) in many chromogranin-A secreting cell cytoplasm. (Immunohistochemical technique $\times 400,10 \mu \mathrm{m}$ )

relatively improvement gastric ulceration ${ }^{[42]}$. Also, strong positive PAS reaction detected in the mucous film over the surface epithelium extending to fill the gastric pits with positive alcian blue stained mucous neck cells. These finding confirmed by SEM in which the mucus sheet covered most of the surface.As previously reported, Ranitidine decrease the ulcerative mucosal changes but with some persistent manifestation. These obtained data are confirmed by ${ }^{[43]}$ who stated that ranitidine is a gastroprotective and antiulcer drug after using it as a standard agent in most non hormonal dependent case.

Different studies investigated sex hormones influence on gastroduodenal mucosa integrity and has shown close association with in sex hormones. This effect explained the possible antiulcer effect of estrogen hormone ${ }^{[4]]}$. Group IV in which rate received combined therapy of ranitidine $\&$ estradiol revealed better improved histological results including mucosa organization and the mucous barrier The finding confirmed by SEM and different stains. Estrogens have been shown to inhibit gastric acid secretion in female human and animal studies ${ }^{[19]}$. Oestrogen increase calcitonin gene related peptide (CGRP) levels in sensory nerve-endings leading to increased blood flow through vasodiltation. Subsequently, It decreases PG and inhibits activation of neutrophils reducing possible inflammatory response ${ }^{[45]}$. Also, it was reported that this protective mechanism of estrogen explains female resistance to gastric mucosal ulceration during fertile period ${ }^{[46]}$.

Regarding to the collagen fiber, this study investigated the amount of collagen fiber in experimental and control groups. It was found that collagen fiber increased in group II with some reduction in group treated with ranitidin . While in group treated with both ranitidine and estradiol, its amount was observably decreased. There is 

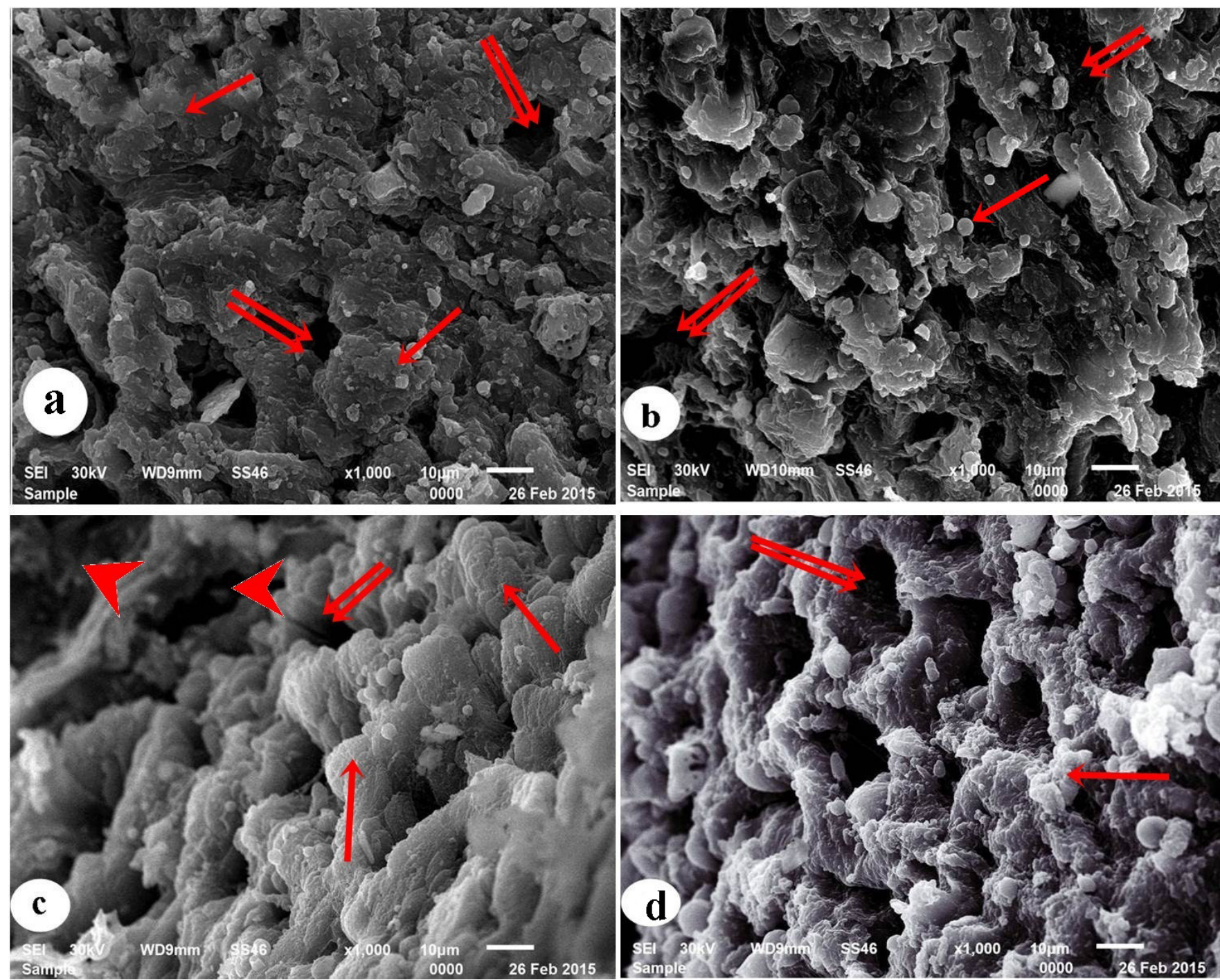

Fig 7: (a): SEM of the control group showing mucous sheet covering the whole surface mucous cells (arrow), gastric pits (double arrow) are also seen. (b): group II reveals wide gastric pits ( double arrow), globular mucous (arrow) is appeared. (c):In group III mucous sheet cover most of the surface mucous cells (arrow). Globular mucous and some narrow gastric pits (double arrow) and others are wide (arrow head). (d): groupIV reveals mucous sheet covering the surface mucous cells (arrow), relatively narrow gastric pits (double arrow) are also noticed. $(\mathrm{SEM} \times 1000,10 \mu \mathrm{m})$

myofibroblasts located beneath the epithelium of gastric mucosa. When ulcer occur these cells wandered to its bed and form granulation tissue ${ }^{[47,48]}$. Also, the fibroblasts yield collagen fibrils and other extracellular matrixes to form ulcer scar. On the other hand, collagen fiber attenuated in bothe orher group with more improvement and decrease in estrogen supplemented group. This in accordance with ${ }^{[49]}$.

In this work, MDA increased in tissue and serum with decreased in antioxidant enzymes( serum catalase ,SOD and tissue reduced glutathione) in ulcerated ovariectomized rats. Same results detected by other researchers ${ }^{[50]}$ who mentioned that significant increase MDA (malondialdehyde) caused by indomethacin application. They stated that indomethacin induced mucosal damage not only by inhibiting cyto-protective synthesis of PG but also by upsetting the oxidant/antioxidant mechanisms. So also, catalase activity decreases with reduction in superoxide dismutase activity post indomethacin administration in $\mathrm{rat}^{[51]}$. Estrogen proved as stabilizer of redox system by balancing the levels of both oxidant and antioxidant parametres $^{[52]}$

Concerning the role of estrogen receptor alpha and beta, our results presumably indicate that the effect of estrogen on gastric acid secretion and gastric ulceration were more pronounced through estrogen receptor. Enormous cohort study confirmed ER $\alpha$ and ER $\beta$ existence in both gastric tssue either cancerous or non-cancer ${ }^{[53]}$. Recently, Fan Zhou et al. confirmed the presence of ER $\alpha$ and ER $\beta$ in stomach by immunohistochemistry ${ }^{[54]}$. Estrogen acts on intracellular receptor (ERs), which mediates its cellular actions that are found in gastric tissue (both cancerous and non-cancerous) and regulates its action . It was shown that $17 \beta$-estradiol binds well to both ERs equally and it is the most potent ER $\beta$ endogenous ligand ${ }^{[4]}$. As in this work, a 
significant reduction of ER $\alpha$ and ER $\beta$ mRNA expression established in ovariectomized ulcer-induced group when compared with controls. Also, group treated with rantiidine and estradiole showed significant increase of expression of both when compared to the untreated rats. Interestingly, the group treated with ranitidine and estradiole showed a significant up-regulation of the expression of both genes when compared to the treated rats with ranitidine only. Epidemiological studies reported also lower prevalence of peptic ulcer disease in women than $\operatorname{men}^{[11]}$, while pregnant women or women taking estrogen containing oral contraceptive pills exhibit a further reduced frequency of gastrodudenal ulcer ${ }^{[5]}$.

The stomach function facilitated and regulated by both neuronal transmitters and neuropeptides. They released by group of neuroendocrine cells and play role in motility regulation, acid secretion, hormonal release, local blood flow and mucosal defence mechanisms ${ }^{[55]}$. Regarding to immunohistochemical results, faint positive immuoreaction was seen in ulcer group indicating destruction of these cells in damaged mucosa. However, Strong positive immuoreaction returned in some cells with ranitidine treatmen, better reaction revealed in combined therapy. Gastric ulcer induced by PG inhibitory effect on acid secretion. This action mediated in either ways, directly by acid secretion inhibition at parietal cells and indirectly by enterochromaffin-like (ECL) cells inhibition ${ }^{[66,57]}$

Animal studies support that female rats have reduced gastric ulcer formation and by its potential protective antiulcer effect of estrogen. They hypnotized mucosal defense mechanisms that maintained the gastric mucosal integrity. These mechanisms divided into three levels: A pre epithelial (mucus-bicarbonate), epithelial including tight junctions and fast cell turnover, and a sub-epithelial levesl, primarily the blood flow ${ }^{[58]}$. Several clinically relevant showed that ER $\alpha$ stimulation could sufficiently elicit several biological responses that attributed to estrogen action including antiulcer and antioxidant activity ${ }^{[59]}$. Also, $\mathrm{ER} \alpha$ anti-inflammatory activity has been established in many epidemiological and experimental studies ${ }^{[60,61]}$

This study revealed that estrogen suplentation decreases the possibility of gastric ulcer in postmenopausal women. It was revealed that ranitidine treatment alone minimally improve the ulcer in ovariectomized female rats however estradiol combination with this drug induced better improvement in both histological and biochemical alterations. We concluded that postmenopausal women should supplemented with estrogen not only to control menopausal symptoms but to protect and maintained gastric mucosal integrity.

Recommendation: . Estrogen has a unique roles in attenuation of gastric ulcer in menopausal women that could be beneficial for potential pharmacotherapeutic advance of hormone replacement therapy( HRT). Also, using estrogen might have a promising effect in protection of GIT mucosa. Further study of estrogen and ERs in gastrointestinal system could yield unique targets for the management of any GIT diseases

\section{CONFLICT OF INTEREST}

All authors declare No Conflict of interest

\section{REFERRENCES}

1. Ibrahim BMM, Salama AAA, Abdallah HMI, ElAwdan SA, Shaffie, NM. Study of the protective effects of flaxseed oil on ethanol induced gastric mucosal lesions in non ovariectomized and ovariectomized rats. international Journal of pharmacology.2015; 12(40):329-339

2. Al-Wajeeh NS, Hajerezaie M, Noor SM, Halabi MF, Al-Henhena N, Azizan AHS, Kamran S, Hassandarvish P, Shwter AN, Karimian H, Ali HM, Abdulla MA. The gastro protective effects of Cibotium barometz hair on ethanol-induced gastric ulcer in Sprague-Dawley rats.BMC Veterinary Research 2017; 13(27):1-12

3. Zaki SM, Mohamed EA. Effect of glucocorticoids on indomethacin-induced gastric ulcer in the male albino rat-Histological, morphometric and electron microscope study. Arch Med Sci.2014; 10(20):381-388

4. Shore R, Bjorne H, Omoto Y, Siemiatkowska A, Gustafsson J, Lindblad M, Holm L. Sex differences and effect of estrogen in rat gastric mucosal defence. World J Gastroenterol. 2017;23(3):426-436

5. Kumral ZNO, Memi G, Ercan F, Yegen BC Estrogen allivates acitic acid-induced gastritis or colonic damage via both ER $\alpha$ - and ER $\beta$-mediated and direct antioxidant mechanisms in rats. Inflammation 2014; 37(3):694-705

6. Perico LL, Rodrigues VP, Ohara R, Bueno G, Nunes VV, Dos-Santos RC, Camargo A.C et al. Sex-specific effects of Eugenia punicifolia extract on gastric ulcer healing in rats. World Journal of Gastroenterology 2018;14(38):4369-4383.

7. Ashokan KV, Kurane MM, Pillai MM. Effect of ovariectomy and estrogen administration upon duodenal ulceration inducd by cysteamine. IUFS journal of Biology 2010; 69:6-17

8. Sangma TK, Jain S, Mediratta PK. Effect of ovarian sex hormones on non-steroidal anti-inflammatory drug-induced gastric lesion in female rats.Indian journal of pharmacology 2014; 46(1): 113-116 
9. Akpamu V, Owoyele VB, Ozor M, Osifo VC. Indomethacin- induced gastric ulcer:Model in female Wistar rats. International journal of basic , applied and innovative research(IJBAIR) 2013; 2(4):78-84

10. Simpson ER. Sources of estrogen and their importance. J Steroid Biochem Mol Biol. 2003;86:225-230.

11. Yang X, Guo Y, Jialin H, Zhang F, Sun X, Yang $\mathrm{S}$, Dong $\mathrm{H}$. Estrogen and estrogen receptor in the modulation of gastrointestinal secretion. Oncotarget 2017;8 (57):97683-97692

12. El-Tablawy NM, Omran MM, Khowailed AA, Tantawy EE. Effect of estrogen on basal, charbacol stimulated acid secretion and indomethacin induced ulcer in female albino rats. Med. J Cairo University 2012; 80(1):533-544.

13. Ds Simone V, Matteoli G. Estrogen-Mediated Effects Underlie Gender Bias in Inflammatory Bowel Disease.Cellular and Molecular gastroenterology and Hepatology 2018; 5 (4):638639

14. Levin ER. Extranuclear steroid receptors are essential for steroid hormone actions. Annu Rev Med. 2015; 66:271 280

15. Brusselaers N, Maret-Ouda J, Konings P, El-Serag HB, Lagergren J. Menopausal hormone therapy and the risk of esophageal and gastric cancer. Int J Cancer 2017;140:1693-1699.

16. Smith A, Contreras C, Ko KH, Chow J, Dong X, Tuo B, Zhang H, Chen D, Dong H Gender-specific protection of estrogen against gastric acid-induced duodenal injury :stimulation of duodenal mucosal bicarbonate secretion. Endocrinology 2008; 149(9):4554-4566

17. Frycz BA, Murawa D, Borejsza-Wysocki M, Wichtowski M, Spychala A, Marciniak R, Murawa P, Drews M, Jagodzinski PP. mRNA expression of steroidogenic enzymes, steroid hormone receptors and their coregulators in gastric cancer .Oncology Letters 2017 ; 13:3396-3378

18. Keshavarzi Z, Hadad MK, Zahedi MJ, Bahrami A. The effect of female sex steroids on gastric secretory resposes of rat following traumatic brain injury.Iranian Journal of Basic Medical Science 2011;14(3):231-239
19. Akpamu U, Otamere HO, Ernest-Nwoke IO, Ekhator CN, Osifo UC. The protective effect of testosterone on indomethacin-induced gastric ulcer in female Sprague dawley rats. Advances in EndocrinologyVol.2016;1-5.. Article ID 3452760

20. Ajiboye KI, Oluwole FS, Ajiboye OF. Effect of L-arginine supplementation on indomethacininduced gastric ulceration in rats.journal of research and development 2014;1(8):8-16

21. Shimozawa N, Okajima K, Harada N. Estrogen and isoflavone attenuate stress-induced gastric mucosal injury by inhibiting decrease in gastric tissue level of CGRP in ovariectomizes rats. American Journal of gasterointestinal and liver physiology 2006; 5:1-41

22. Abdel-Raheem I, Bamagous G, Omran G. Anti-ulcerogenic effectof genistein against indomethacin-induced gastric ulcer in rats.Asian Journal of Pharmaceutical and Clinincal Research 2016; 9(2):58-63

23. Khalefa AA, Abd Alaleem DI, Attiaa KI. The protective effects of ghrelin and leptin against stress-induced gastric ulcer in rats. Arab J Gastroenterol. 2010; 11:74-78.

24. Radwan AG, West GB. Effect of aminoguanidine, chlorpromazine and NSD-1055 on gastric secretion and ulceration in the Shay rat.British Journal of pharmacology 1971; 41(1):167-169

25. Radwan AG, Ghaleb HA. The effect of doxepin and benzquinamide in comparison with chlorpromazine on gastric acid secretion and ulceration in the rat. Al-Azhar Med. J.1974; 3(1): 85-90.

26. Aebi H. Catalase in Vitro. In Packer, L., (Ed.), Methods in Enzymology, Academic Press, San Diego 1984; 10: 121-126.

27. Tena-Sempere M, Navarro VM, Mayen A, Bellido C, Sa'nchez-Criado JE. Regulation of Estrogen Receptor (ER) Isoform Messenger RNA Expressionby Different ER Ligands in Female Rat Pituitary. Biology of Reproduction 2004; 70: 671-67

28. Livak KJ, Schmittgen TD. Analysis of relative gene expression data using real-time quantitative PCR and the 2 (-Delta Delta C(T)) method. Methods 2001; 25(4):402-8. 
29. Bancroft J, Layton C. Hematoxylin and eosin. In: Suvarna SK, Layton C and Bancroft JD (ed). Theory and Practice of histological techniques. $7^{\text {th }}$ edition. Churchill Livingstone of El Sevier, Philadelphia 2013; 172-214.

30. Goodhew P, Humphreys J, Beanland R. In: Electron Microscopy and Analysis, $3^{\text {rd }}$ ed. Taylor and Francis, London, New York 2001; Pp: 237 255.

31. Ur Rahman MS, Cao J. Estrogen receptors in gastric cancer: Advances and perspectives. World J Gastroenterol. 2016;22: 24752482

32. Ohtani M, Ge Z, García A, Rogers AB, Muthupalani S, Taylor NS, Xu S, Watanabe K, Feng Y, Marini RP et al. $17 \beta$ estradiol suppresses Helicobacter pylori induced gastric pathology in male hypergastrinemic INS GAS mice. Carcinogenesis 2011; 32:1244 1250

33. El-Awdan SA, Zaki HF, Abdelsalam OM, ElIraqy WI, Kenawy SA. Impact of dopaminergic system on mucosal integrity in indomethacininduced gastric ulcer in rats:Possible modulation by ranitidine or L-carnitine. Pharmacologica 2013;4(1):22-33

34. Nabavizaden F, Alizaden AM, Sadroleslami Z, Adeli S. Gastroprotective effects of amygdaline on experimental gastric ulcer: role of $\mathrm{NO}$ and TNF- $\alpha . J o u r n a l$ of medical plants research 2011; 5(4):3122-3127

35. Fukumoto $\mathrm{K}$, Naito $\mathrm{Y}$, Takagi $\mathrm{T}$, Yamada $\mathrm{S}$, Horie R, Inoue K, Harusato A, Hirata I, Omatsu $\mathrm{T}$, Mizushima $\mathrm{K}$ et al. Role of tumor necrosis factor- $\alpha$ in the pathogenesis of indomethacininduced small intestinal injury in mice. International Journal of Molecular Medicine 2011; 27:353-359.

36. Al-Asmari A, Al-Omani S, Al-Otaibi M, AlAbdulaaly A, Elfaki I, Al-Yahya K, Arshaduddin M. Gastroprotective effect of minocycline in experimentally induced gastric ulcers in rats. International Journal of Clinical and Experimental Medicine 2014; 7(3):583-596.

37. Kamel MA, Hamza RZ, Abdel-Hamid NE, Mahmoud FA. Anti-ulcer and gastroprotective effects of fenugreek, ginger and peppermint oil in experimentally induced gastric ulcer in rats. Journal of Chemical and Pharmaceutical Research 2014; 6(2):451-468.
38. Keshavarzi Z, Mohebbati R, Mohammadzadeh $\mathrm{N}$, Alikhani V.The protective role of estradiol progesterone in male rats,following gastric ischemia-reperfusion.Acta Endocrinologica 2018;104(1):30-35

39. Katary MA, Salahuddin A. Gastroprotective effect of punicalagin against ethanol-induced gastric ulcer:the possible underlying mechanisms. Biomarker Journal 2017; 3(1):3):1-8

40. Sabiu S, Garuba T, Sunmonu TO, Sulyman $\mathrm{AO}$, Ismail NO. Indomethacin-induced gastric ulceration in rats:Ameliorative roles of spondias mombin and ficus exasperate.Pharmaceutical Biology 2016; 54(1):180-186

41. Kurt D, Saruban BG, Kanay Z, Yokus B, Kanay BE, Unver O, Hatipoglu S. Effect of ovariectomy and female sex hormones administration upon gastric ulceration induced by cold and immobility restraint stress. Saudi Med. Journal 2007; 28(7), 1021-1027

42. Abdallah IZA, Khattab HAA, Heeba GH. Gastroprotective effect of Cordia Myxa L. fruit extract against indomethacin-induced gastric ulceration in rats.Life Science Journal 2011;8(3):433-445

43. Sakat SS, Tupe P, Juvekar A. Gastroprotective effect of Oxalis corniculata (whole plant) on experimentally induced gastric ulceration in Wistar rats. Indian Journal of Pharmaceutical Sciences 2012; 74(1):48-53

44. Labrie F. All sex steroids are made intracellularly in peripheral tissue by the mechanisms of intracrinology after menopause. J Steroid Biochem Mol Biol. 2015; 145, 133138

45. Harvey BJ, Condliffe S, Doolan CM. Sex and salt hormones: rapid effects in epithelia. News Physiol Sci. 2001; 16:174-177.

46. Trenti A, Tedesco S, Boscaro C, Trevisi L, Bolego C, Cignarella A. Estrogen, Angiogenesis, Immunity and Cell Metabolism: Solving the Puzzle. Int. J. Mol. Sci.2018; 19: 859:2-16

47. Nishida T, Tsuji S, Kimura A, Tsujii M, Ishii S, Yoshio $\mathrm{T}$ et al. Endothelin-1, an ulcer inducer, promotes gastric ulcer healing via mobilizing gastric myofibroblasts and stimulates production of stroma-derived factors. Am J Physiol Gastrointest Liver Physiol 2006; 29:,G1041-G1050. 
48. Fornai M, Colucci R, Antonioli L, Ghisu N, Tuccori M, Blandizzi C, Frycz BA, Murawa D, Borejsza-Wysocki M, Wichtowski M, Spychala A, Marciniak R, Murawa P, Drews M, Jagodzinski PP. mRNA expression of steroidogenic enzymes, steroid hormone receptors and their coregulators in gastric cancer Oncology Letters 2017;13:33963378 .

49. Dambros M, Palma P, Mandarim de Lacerda C, Miyaoka R, Netto NR. The effect of ovariectomy and estradiol replacement on collagen and elastic fibers in the bladder of rats. international Urogynecology Journal 2003;14 (2):108-12

50. Dursun H, Bilici M, Albayrak F, Ozturk C, Saglam MB, Alp HH, Suleyman H. Antiulcer activity of fluvoxamine in rats and its effect on oxidant and BMC antioxidant parameter in stomach tissue. Gastroenterology 2009;20:9-36

51. Sathish R, Sahu A, Natarajan K. Antiulcer and antioxidant activity of ethanolic extract of Passiflora foetida L. Indian Journal of Pharmacology 2011; 43(3):336-339

52. Kumtepe Y, Borekci B, Karaca M, Salman S, Alp HH, Suleyman H. Effect of acute and chronic administration of progesterone, estrogen, FSH and LH on oxidant and antioxidant parameters in rat gastric tissue. Chem Biol Interact 2009; 182: 1-6

53. Gan L, He J, Zhang X, Zhang YJ, Yu GZ, Chen Y, Pan J, Wang JJ, Wang X. Expression profile and prognostic role of sex hormone receptors in gastric cancer. BMC Cancer 2012; 12:566.

54. Zhou F, Xu Y, Shi J, Lan X, Zou X, Wang L, Huang Q. Expression profile of E-cadherin, estrogen receptors, and P53 in early-onset gastric cancers. Cancer Med. 2016; 5:3403-11.
55. El-Salhy M, Gilja OH, Hausken T. Chromgranin A cells in stomach of patients with sporadic irritable bowel syndrome.Molecular Medicine Reports 2014; 10:1753-1757.

56. Shalaby SA, Eid EM, Ahmed OF, Abdow MF. Protective effect of ascorbic acid and ranitidine on the indomethacin-induced gastric injury in adult albino rats;light and electron microscopy. International Journal of Clinical and Developmental Anatomy 2016; 2(1):1-13.

57. Takeuchi K, Amagase K. Role of prostaglandin $\mathrm{E}$ an $\mathrm{EP}$ receptors in mucosal protection and ulcr healing in the gastrointestinal tract.Mini review. Arch Dig Disord 2017;1(2):8-16

58. Qin J, Liu M, Ding Q, Ji X, Hao Y, Wu X, Xiong $J$. The direct effect of estrogen on cell viability and apoptosis in human gastric cancer cells. Mol Cell Biochem 2014;395: 99-107

59. Rapetti-Mauss, R, O’Mahony F, Sepulveda FV, Urbach V, Harvey BJ. Oestrogen promotes KCNQ1 potassium channel endocytosis and postendocytic trafficking in colonic epithelium. J Physiol.2013; 591:2813-2831.

60. Xu CY, Guo JL, Jiang ZN, Xie SD, Shen JG, Shen JY, Wang LB. Prognostic role of estrogen receptor alpha and estrogen receptor beta in gastric cancer. Ann Surg Oncol.2010; 17: 25032509

61. Kobayashi H, Yoshida S, Sun YJ, Shirasawa N, Naito A. $17 \beta$ Estradiol in the systemic circulation derives mainly from the parietal cells in cholestatic female rats. J Endocrinol Invest 2016;39: 389400 


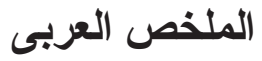

\title{
دور مكملات هرمون الاستروجين في علاج قرحة المعدة التي يسببها الإلدوميتاسين في الجرذان البيضاء (لر اسةُ نسيجية وكيميائية حيوية)
}

\author{
داليا عبد المعين محمد' و سماح محمد أحمد أحمد' و سالى شلبى 'وايمان عبد القادر r

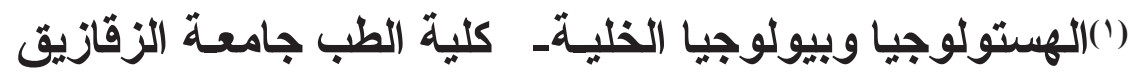 \\ (ن) الكيمياء الحيوية_ كلية الطب جامعة الزقازيق
}

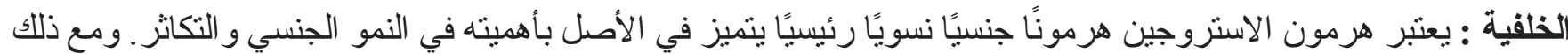

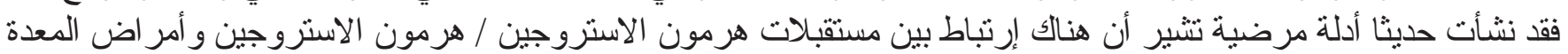

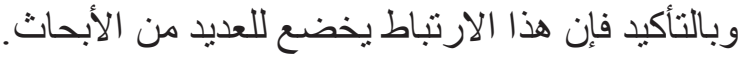

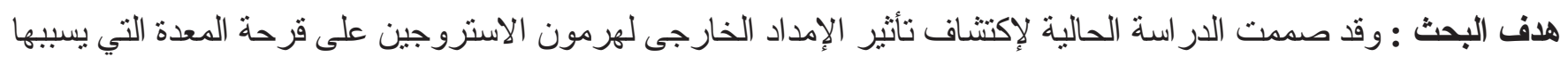

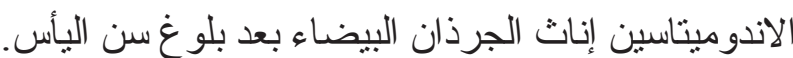

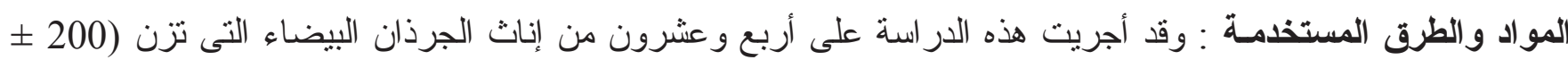

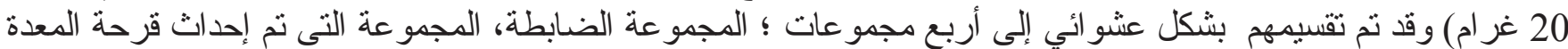

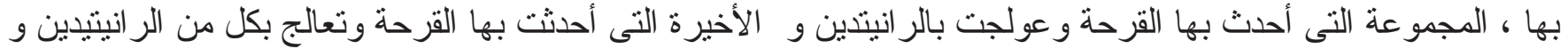

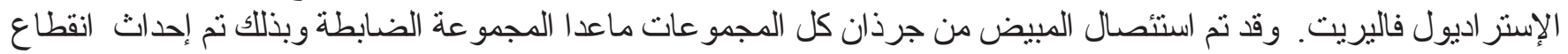

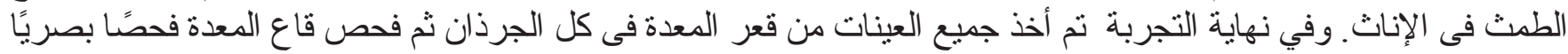

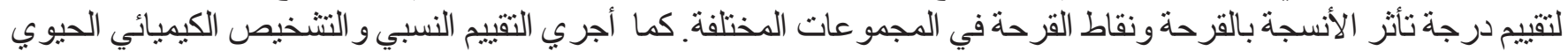
أيضا وتم تحليل جميع النتائج إحصائيا.

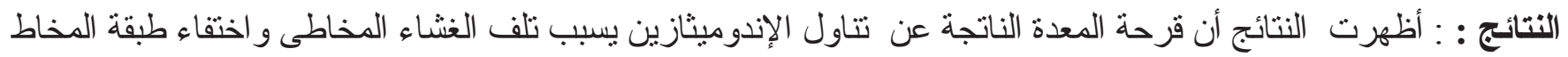

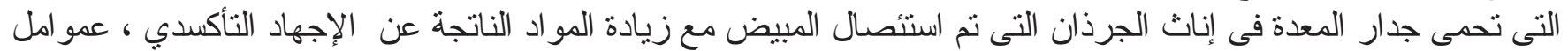

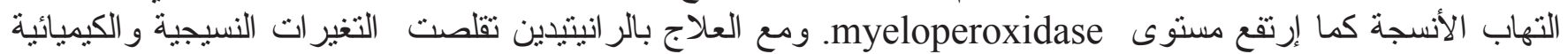

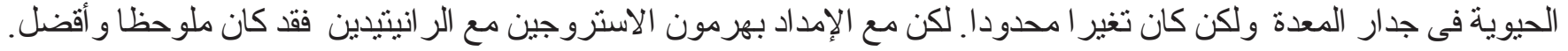

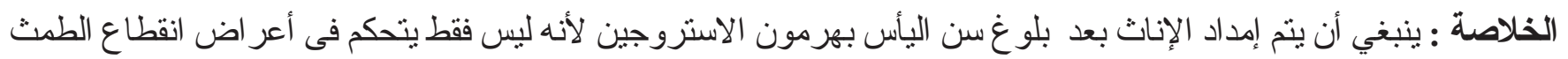

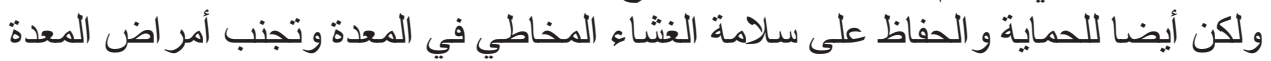

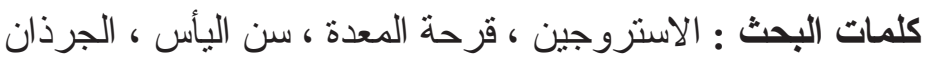

